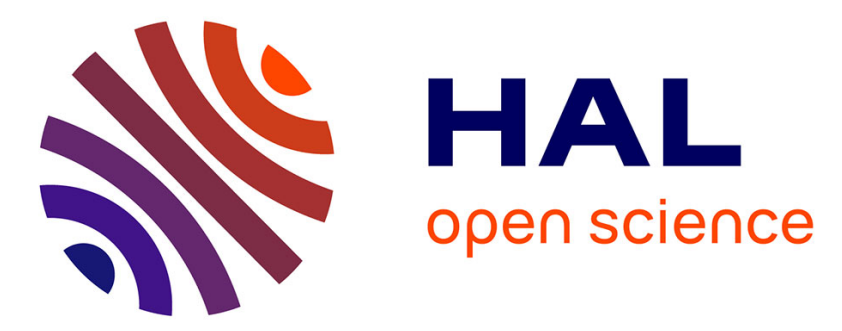

\title{
Annulus fibrosus microstructure: an explanation to local heterogeneities
}

\author{
Adrien Baldit, Dominique Ambard, Fabien Cherblanc, Pascale Royer
}

\section{To cite this version:}

Adrien Baldit, Dominique Ambard, Fabien Cherblanc, Pascale Royer. Annulus fibrosus microstructure: an explanation to local heterogeneities. 39ème congrès de la Société de Biomécanique, Aug 2014, Valenciennes, France. 10.1080/10255842.2014.931092 . hal-01219449

\author{
HAL Id: hal-01219449 \\ https://hal.science/hal-01219449
}

Submitted on 22 Oct 2015

HAL is a multi-disciplinary open access archive for the deposit and dissemination of scientific research documents, whether they are published or not. The documents may come from teaching and research institutions in France or abroad, or from public or private research centers.
L'archive ouverte pluridisciplinaire HAL, est destinée au dépôt et à la diffusion de documents scientifiques de niveau recherche, publiés ou non, émanant des établissements d'enseignement et de recherche français ou étrangers, des laboratoires publics ou privés. 


\title{
Annulus Fibrosus microstructure: an explanation to local heterogeneities
}

\author{
A. Baldit*†‡, D. Ambard $\neq$, F. Cherblanc $\neq$ and P. Royer $\ddagger$ \\ $\dagger$ Department of Mechanical Engineering and INSIGNEO Institute for in silico Medicine, University of Sheffield, UK \\ +LMGC, CNRS, University of Montpellier 2, Place Eugène Bataillon, 34095 Montpellier cedex 5, France
}

Keywords: Annulus Fibrosus; Intervertebral Disc; Hydro-Chemo-Mechanical Model; Finite Element; Digital Image Correlation

\section{Introduction}

Annulus fibrosus (AF) is the outer tissue of intervertebral discs (IVD). Its peculiar microstructure and biphasic composition define by an oriented fibre network embedded in a highly hydrated matrix (60-70\%) is usually assimilated to porous composite material. It confers to AF a nonlinear, viscous and anisotropic behaviour.

Many experimental and numerical studies underlined the anisotropic and non-linear mechanical behaviours on averaged values [Ambard and Cherblanc, 2009; Malandrino et al, 2011] but fail to represent the experimental strain heterogeneities [Baldit et al, 2013a; Michalek et al, 2010], that would be related to the microstructure and the biphasic constitution. On the other hand, characterization rarely relies on volumic behavior but it's relevant when models deal with soft porous media [Baldit et al, 2013b].

This work aims to couple a poro-hyper-elastic model identification with homogenized and discretized geometries highlighting model sensitivity and limits regarding experimental transverse strains measurements.

\section{Methods}

19 pig and 10 human specimens have been carved out from respectively 5 and 3 lumbar IVD to provide samples with dimensions of $\mathrm{L}_{\mathrm{rr}} \mathrm{xL}_{\theta \theta} \mathrm{xL}_{\mathrm{zz}}=4$ x $10 \times 4 \mathrm{~mm}^{3}$. An experimental process has been developed to measure simultaneously stress and transverse strains fields $\left(\mathrm{E}_{\mathrm{rr}}, \mathrm{E}_{\mathrm{zz}}\right)$ during cyclic tensile tests and relaxation tests with in vivo conditions [Baldit et al, 2013a; 2013b]. Strain fields were computed from a digital image correlation (DIC) technique (Kelkins, University of Montpellier 2) performed on both transverse planes. Then, AF tissue was modelled (LMGC90, University of Montpellier 2) with a hyper-elastic and quasi-incompressible porous material [Malandrino et al, 2011; Baldit et al 2013b] to represent the underlying fibres network embedded in an isotropic, porous matrix. First of all, the parameters characterization has been performed on a simplified geometry for computational cost reasons [Baldit et al, 2013b]. This geometry was focused on central part $\left(\mathrm{L}_{\theta \theta}=1 \mathrm{~mm}\right)$ assuming that sample ends were rejected to infinity in circumferential direction. Furthermore, considering a homogeneous material, radial and vertical symmetries have been used to work with a 169 elements mesh.

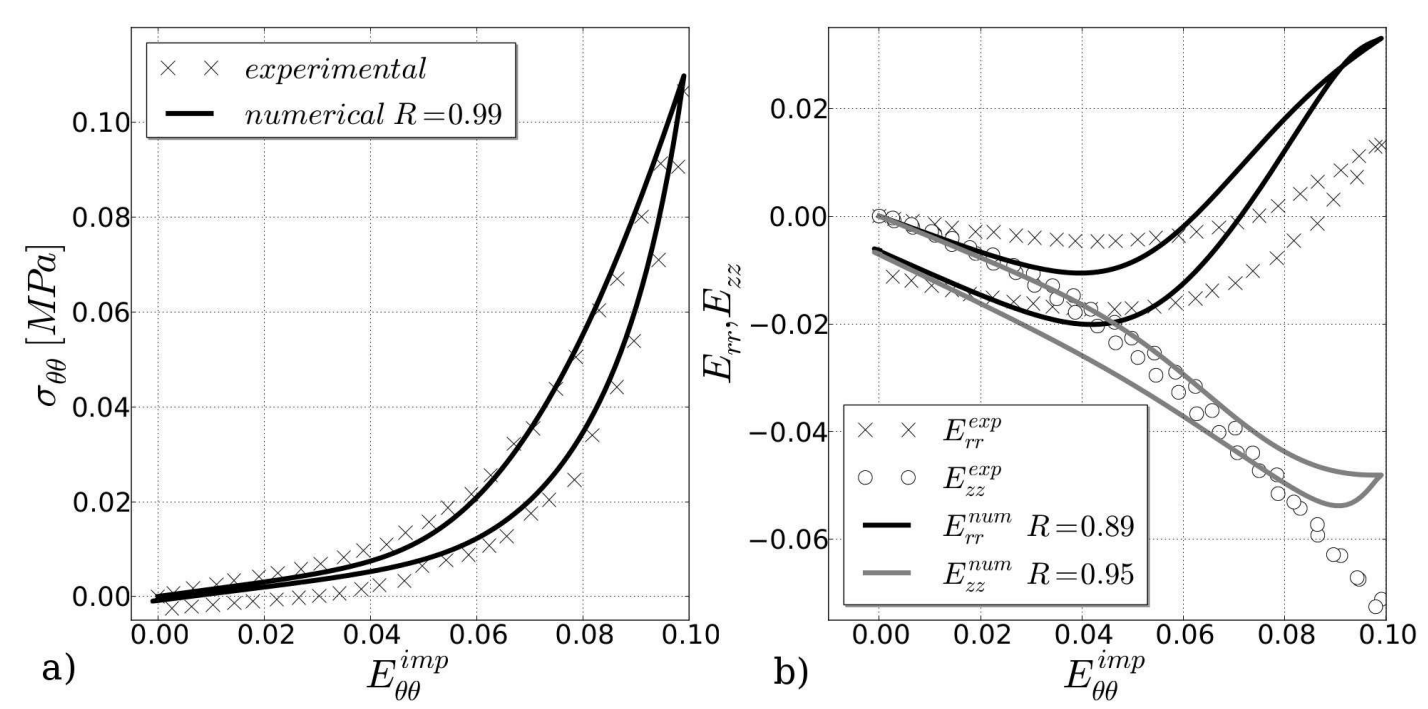

Figure 1 Experimental and numerical results on a) stress (Piola- Kirchhoff 1) and b) averaged transverse strains as function of imposed circumferential strain. 


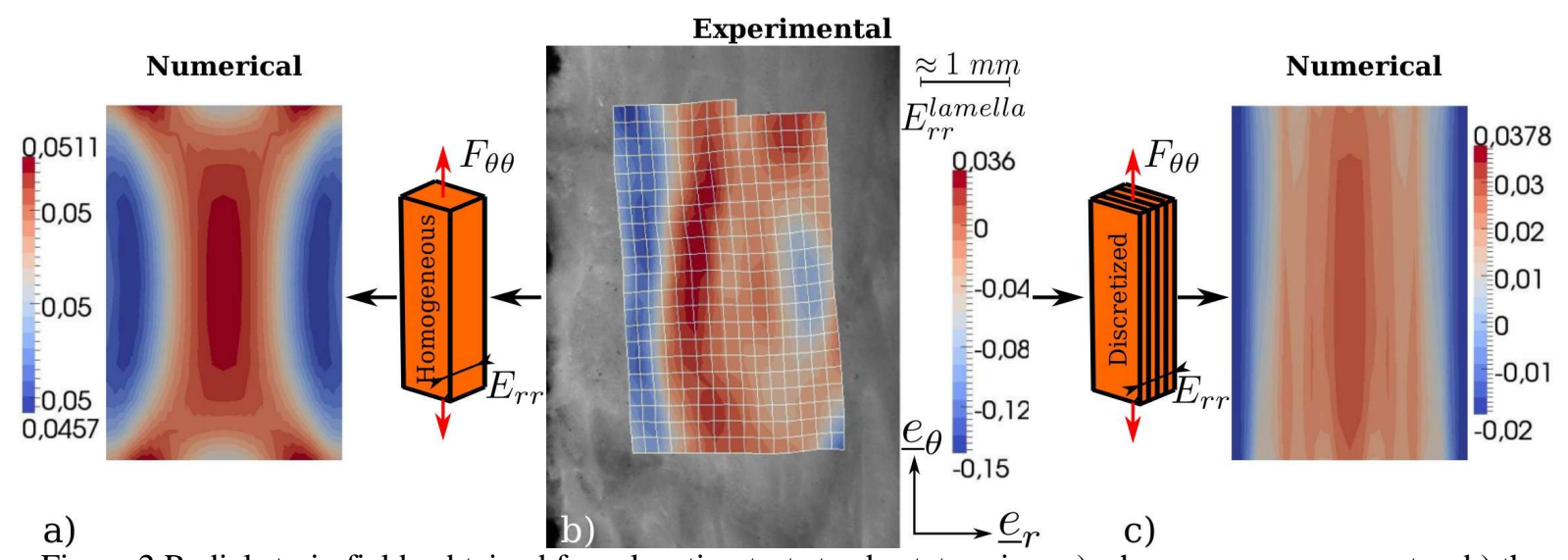

Figure 2 Radial strain fields obtained for relaxation test steady state using: a) a homogeneous geometry, b) the experimental DIC result and c) a dicretized geometry on the same sample than Fig.1.

Then, the real complete sample geometry allowed comparing numerical and experimental strain fields using experimental boundary conditions plus the right number of lamellae. Therefore, the vertical symmetry cannot be used anymore and the element number reached 5280 or 10560 depending on impair (radial symmetry used) or pair lamellae number.

\section{Results and Discussion}

Experimental results exhibit the classical non-linear stiffening behaviour with hysteresis under loading cycles on Fig.1a [Ambard and Cherblanc, 2009]. Furthermore, the anisotropic behaviour clearly appears on averaged transverse strain fields illustrated on Fig.1b. Compared to the fibre plane where a strong shrinkage is systematically observed, three main behaviours have been captured in lamellae plane with a shrinkage, a progression from shrinkage to swelling (Fig.1b) or a swelling [Baldit et al, 2013a]. It's noteworthy that when swelling appeared, we systematically obtained a shrinkage/swelling/shrinkage pattern as illustrated on Fig.2b.

The identification on simplified geometry provided parameters values for each sample leading to represent their behaviours in circumferential stress and in averaged transverse strains Fig.1 with averaged correlation coefficient $(\mathrm{R})$ values of 0.99 on stress and respectively 0.11 and 0.78 on radial and vertical averaged strains. Therefore, something was missing in our model to correlate experimental and numerical results in radial direction.

Simulations at sample scale, Fig.2a and 2c, showed that real boundary conditions don't play a major role on central part and comfort our first assumption. Although, we can notice that the whole sample swells with a homogeneous geometry while the discretized one allows to obtain the experimental pattern. Moreover, interesting local values appear on swelling part, while in vertical boundaries we cannot reach the strong experimental shrinkage.

\section{Conclusions}

Uniaxial tensile test enriched by DIC transverse strain measurements improves the hydromechanical behaviour characterization of soft biological tissues. To work at AF tissue level, it appears that the homogeneity assumption doesn't allow to fairly describe the heterogeneous strain pattern observed experimentally.

Nowadays, research is focused on interaction between tissue and cell scales to model tissue development and renewal [Malandrino et al, 2011]. These results highlight the limit of main literature simulations unable to reach the local mechanical cell environment. This work will be used within an inverse method taking into account full strain fields to obtain an accurate tissue description useful for multiscale predictive models.

\section{References}

Ambard D. and Cherblanc F., Mechanical behavior of annulus fibrosus : a microstructural model of fibers reorientation, Ann Biomed Eng, 37, 11:2256-2265, 2009.

Baldit A., Ambard D., Cherblanc F., and Royer P., Experimental analysis of the transverse mechanical behaviour of annulus fibrosus tissue, Biomech Model Mechanobiol, 2013a

Baldit A., Ambard D., Cherblanc F. and Royer P., Mechanical behaviour of annulus fibrosus tissue: identification of a poro-hyper-elastic model from experimental measurements. Comput Meth. in Biomech. and Biomed. Eng., Vol. 16, 280-281, 2013b.

Malandrino A., Noailly J. and Lacroix D.. The effect of sustained compression on oxygen metabolic transport in the intervertebral disc decreases with degenerative changes, PLoS Comput Biol, Vol. 7, e1002112, 2011.

Michalek A. J., Buckley M. R., Bonassar L. J., Cohen I., and Iatridis J. C., The effects of needle puncture injury on microscale shear strain in the intervertebral disc annulus fibrosus, The Spine Journal, 10(12): 1098 - 1105, 2010. 